\title{
ADAPTABILITY AND GRAIN YIELD STABILITY OF RICE HYBRIDS AND VARIETIES IN VENEZUELA
}

\author{
Marco Acevedo-Barona ${ }^{1}$, Rubén Silva-Díaz $^{1}$ and Ramón Rea-Suárez ${ }^{2}$
}

\begin{abstract}
The development of new high-performance and stable cultivars requires test multi-environmental validation to deal with the effect of genotype by environment interaction (GEI). With the objective to determine adaptability and stability for grain yield in hybrids and rice varieties through the models AMMI, SREG and REML/BLUP. Six experiments were evaluated during the 2015-2016 dry season in the main producing regions of Venezuela. The ANOVA detected differences for genotype $(\mathrm{G})$, environment (E) and their interaction (GEI), representing 19, 65 and $16 \%$ of the total variation, respectively, with prevalence of hybrid by localities interaction. The first major components of the AMMI and GGE biplot models explained 77 and $83 \%$ of GEI, respectively. The three models coincided and identified the hybrid RHA-180 (H6) with improved average performance, adapted and stable. The hybrid HIAAL (H3) was the most prominent. Among the checks, 'Pionero FL' (V3) was the most stable with moderate yield; the opposite occurred with 'Soberana FL' (V4) and 'SD-20A' (V1), that the AMMI and GGE biplot models identified with high and unstable performances and specific adaptation to locality INIA Guárico (L1), not coinciding with the mixed model. Two megaenvironments were identified with the winning genotypes H6 and V4. There was divergence between AMMI and GGE biplot to identify discriminatory and representative locations. The Plot 199 (L3) was the most representative, while the location L1 discriminated better the genotypes. The GGE biplot analysis was more informative and complete for the GEI analysis.
\end{abstract}

Additional keywords: AMMI, GGE biplot, Oryza sativa, REML/BLUP

\section{RESUMEN}

Adaptabilidad y estabilidad del rendimiento de granos en híbridos y variedades de arroz en Venezuela

El desarrollo de nuevos cultivares estables y de alto desempeño requiere de validación en ensayos multi-ambientales para establecer el efecto de la interacción genotipo por ambiente (IGA). Con el objetivo de determinar adaptabilidad y estabilidad para rendimiento de granos en seis híbridos y cuatro variedades de arroz a través de los modelos AMMI, SREG y REML/BLUP, fueron evaluados seis experimentos durante la época seca 2015-2016 en las principales regiones productoras de Venezuela. El análisis de variancia detectó diferencias para genotipo (G), ambiente (E) e IGA, representando 19, 65 y $16 \%$ de la variación total, respectivamente, predominando la interacción híbridos por ambiente. Los dos primeros componentes principales de los modelos AMMI y GGE biplot explicaron 77 y $83 \%$ de variancia de la IGA. Los tres modelos coincidieron e identificaron al híbrido RHA180 (H6) con mejor desempeño medio, adaptado y estable. El híbrido HIAAL (H3) fue el más destacado. Entre los testigos, 'Pionero FL' (V3) fue el más estable con rendimiento moderado; lo contrario ocurrió con 'Soberana FL' (V4) y 'SD20A' (V1) en los que los modelos AMMI y GGE biplot identificaron altos e inestables rendimientos y adaptación específica a la localidad (L1), no coincidiendo con el modelo mixto. Fueron identificados dos mega-ambientes con los genotipos superiores (H6) y (V4). Hubo divergencia entre AMMI y biplot GGE para identificar localidades discriminatorias y representativas. La localidad Parcela 199 (L3) fue la más representativa, mientras que INIA Guárico (L1) discriminó mejor los genotipos. El análisis GGE biplot resultó más informativo y completo para el análisis de IGA.

Palabras clave adicionales: AMMI, GGE Biplot, Oryza sativa, REML/BLUP

\section{INTRODUCTION}

Rice is sown in almost all the latitudes and contributes approximately $28.55 \%$ of world cereal production, occupies the second place in production and planted area and is consumed by more than $50 \%$ of the world population (FAO, 2019).

Heterosis, known as hybrid vigor, is a phenomenon where heterozygous hybrids show

Received: Febrero 18, 2021

Accepted: June 30, 2021

${ }^{1}$ Instituto Nacional de Investigaciones Agrícolas, INIA CENIAP, Maracay estado Aragua, Venezuela

e-mail: macevedo@inia.gob.ve (autor para correspondencia); rubenjsilvad@gmail.com

${ }^{2}$ Fundación Instituto de Estudios Avanzados (IDEA), Venezuela. e-mail: ramonrea13@ gmail.com 
182

superior performance to their parents. The gene interactions between the two genomes such as dominance, overdominance, and epistasis have been suggested to explain the increased yield and biomass (Fujimoto et al., 2018). The hybrid rice often has a 10-20\% rise in grain yield per unit area compared to the inbred line (Liu et al., 2019). In Latin America, conventional varieties generally show superior performance, attributed to their greater adaptability (Torres, 2014). However, high yields are closely influenced by genotype and genotype by environment interaction (GEI).

There are several biometric models proposed to analyze the GEI and explore adaptability and stability. However, multiplicative models that look at the response of genotypes to specific environments or to different environments have more accurate criteria to analyze this phenomenon in different crops (Costa et al., 2020; Goncalves et al., 2020; Garcia et al., 2021).

Crossa et al. (1990) and Gauch (1992) proposed the application of multivariate models to analyze and interpret the GEI. They recommended the AMMI model (additive main effect and multiplicative interaction) that integrates ANOVA and principal component analysis (PCA) into a combined approach. This analysis permits an improved estimate of the performance of a genotype in an environment allowing estimating a particular effect of the GEI for all genotypes in all environments. The genotype with the lowest absolute value (s) score is considered the most stable. From the first significant and representative principal component (PC), it is said that it concentrates the greatest variance of the GEI, being possible to generate a double representation biplot graph with the grain yield, which shows the similarities (homogeneous groups) of genotypes and environments.

Yan et al. (2000) proposed a modification of the conventional AMMI model, called the site regression model (SREG), which include GGE (Genotype and Genotype by Environment Interaction) in the bilinear terms and provide a graphical analysis of easy interpretation termed GGE biplot. This model considers the main effect of genotype (G) together with GEI as a multiplicative effect, where the adaptive capacity of genotypes is more important than agro-climatic conditions. A biplot is constructed with the first two principal components of the PCA (Camargo et al., 2011). The model accepts grouping the environments into mega-environments, identify genotypes that have broad or specific adaptation for each environment or group of environments and analyze the study of the "ideal genotype", associated with the genotype that meets the premises of high productivity and phenotypic stability (Yan and Kang, 2003).

The maximum restricted likelihood analysis/best linear unbiased estimator (REML/BLUP), also known as a mixed model, considers the effect of genotypes as random and allows the analysis of adaptability, genotypic and non-phenotypic stability as the previous models, adjusting the data for the effects of environments, and, at the same time, predicts the genetic values of the genotypes. The analysis is based on the assumption that the lower the standard deviation of genotypic performance among locations, the greater the harmonic mean of their genotypic values (HMGV). Then, the selection based on the highest values of this variable implies the simultaneous selection for productivity.

In Latin America, including Venezuela, there are few published works on adaptability and performance stability in rice hybrids. However, in Venezuela there are published works on elite lines and varieties of irrigated rice (Acevedo et al., 2010; Acevedo et al., 2019).

The objective of this work was to analyze the GEI and identify adaptability and stability of rice genotypes in six environments in the main producing regions of Venezuela using AMMI, biplot GGE and BLUP models.

\section{MATERIALS AND METHODS}

Plant material, environments and experimental design. Ten genotypes were evaluated, consisting of six advanced hybrids 'HL23057H(A)' (H1), 'HL23057H(B)' (H2), 'HL23035H' (H3), 'HL23021H' (H4) of the nursery from Rice Hybrids for Latin America (HIAAL) of the Latin American Fund for Irrigated Rice (FLAR, for its Spanish acronym); and 'RHA-147' (H5) and 'RHA-180'(H6) of the Danac Foundation, used as experimental materials, and four inbreed varieties 'SD-20A' (V1), 'Payara FL' (V2), 'Pionero FL' (V3) and 'Soberana FL' (V4) as check materials. 
The sowing was carried out during the dry season (November-April) 2015-2016, in the localities presented in Table 1. The sowing system used was dried seed covered at a density of 40 and
$100 \mathrm{~kg} \cdot \mathrm{ha}^{-1}$ for hybrids and varieties, respectively. The agronomic management used in all the experiments were similar to those adopted by the growers in each territory.

Table 1. Characteristics of the six localities used for rice evaluation, season 2015-2016

\begin{tabular}{|c|c|c|c|c|c|}
\hline \multirow{2}{*}{ Location } & \multicolumn{2}{|c|}{ Coordinates } & \multirow{2}{*}{$\begin{array}{l}\text { Altitude } \\
\text { (m) }\end{array}$} & \multirow{2}{*}{$\begin{array}{l}\text { Rainfall } \\
\text { (mm) }\end{array}$} & \multirow{2}{*}{$\begin{array}{c}\text { Mean temperature } \\
\left({ }^{\circ} \mathrm{C}\right)\end{array}$} \\
\hline & $\mathrm{N}$ & $\mathrm{W}$ & & & \\
\hline L1(INIA Guárico) & $08^{\circ} 44^{\prime}$ & $67^{\circ} 31^{\prime}$ & 80 & 1039.4 & 29.7 \\
\hline L2 (Parcel 178) & $08^{\circ} 47^{\prime}$ & $67^{\circ} 32^{\prime}$ & 85 & 986.6 & 28.8 \\
\hline L3 (Parcel 199) & $08^{\circ} 46^{\prime}$ & $67^{\circ} 33^{\prime}$ & 83 & 1101.5 & 28.1 \\
\hline L4 (Aproscello) & $09^{\circ} 28^{\prime}$ & $69^{\circ} 04^{\prime}$ & 128 & 1275.6 & 27.8 \\
\hline L5 (Asoportuguesa) & $09^{\circ} 26^{\prime}$ & $69^{\circ} 03^{\prime}$ & 131 & 1371.6 & 27.5 \\
\hline L6 (INIA Barinas) & $08^{\circ} 33^{\prime}$ & $70^{\circ} 08^{\prime}$ & 156 & 1415.7 & 26.8 \\
\hline
\end{tabular}

Source: INIA (2020)

The experiments were laid out in a randomized complete block design with three replications. The experimental plot was $12 \mathrm{~m}^{2}$ (8 rows of $5 \mathrm{~m}$ long and $0.30 \mathrm{~m}$ apart) with effective harvest area of $9 \mathrm{~m}^{2}$. Grain yield at $12 \%$ moisture was the evaluated character.

Statistical analysis. The grain yield data for ten genotypes in six locations were used in a combined analysis of variance (ANOVA) to determine the effects of location, genotype and their interactions. The source of genotype variation contains (hybrids and varieties), this allowed the decomposition of degrees of freedom, through orthogonal contrasts. The analyzes were carried out using the Agricolae Library of the $\mathrm{R}$ software (http://www.R-project.org).

Biometrical models for adaptability and stability. AMMI model

The model $y_{i j}=\mu+g_{i}+a_{j}+\sum_{n=1}^{N}\left(I P C A_{n}^{g i}\right)\left(I P C A_{n}^{a j}\right)+$ $d_{i j}+\varepsilon_{i j}$, which describes the mean response of a genotype in a given environment (Zobel et al., 1988), was used, where $\mu$ : general mean, $g_{i}$ : genotypic effect, $a_{j}$ : environment effect, and $\varepsilon_{i j}$ : experimental error. The GEI is denoted as $\left(I P C A_{n}^{g i}\right)$ and represents the score of the PC of genotype $i$ for the $\mathrm{n}$ axis; $\left(I P C A_{n}^{a j}\right)$ is the PC of the environment $\mathrm{j}$ for the $\mathrm{n}$ axis; $n$ represents the number of axes used in a particular analysis whose minimum number is $[(g-1)(a-1)]$; and $d_{i j}$ is the residual effect of the GEI that is not explained by the ACP.

Site regression model (SREG) using GGE biplot. The biplot was constructed according to the following model $y_{i j}-\mu-b_{j}=\left(\lambda_{1} \xi_{i 1} n_{j 1}\right)+$ $\left(\lambda_{2} \xi_{i 2} n_{j 2}\right)+\varepsilon_{i j}$, where $\mathcal{Y}_{i j}$ corresponds to the average yield of genotype i $(i=1 \ldots 10)$ in environment $\mathrm{j}(\mathrm{j}=1 \ldots 6) ; \mu$ is the general mean, $b_{j}$ ambient effect $\mathrm{j} ;\left(\lambda_{1} \xi_{i 1} n_{j 1}\right)$ represents the first principal component (PC1); $\left(\lambda_{2} \xi_{i 2} n_{j 2}\right)$ represents the second principal component (PC2); $\lambda_{1}$ and $\lambda_{2}$ are the eigenvalues associated with PC1 and PC2, respectively; $\xi_{i 1}$ and $\xi_{i 2}$ the autovectors of genotypes $\mathrm{i}$ for the first and second principal components, respectively; $n_{j 1}$ and $n_{j 2}$ the autovectors of environments $\mathrm{j}$ for the first and second principal components, respectively; $\varepsilon_{i j}$ the experimental error associated with genotype $i$ in the environment $\mathrm{j}$. The AMMI and GGE biplot analyzes were performed using the $\mathrm{R}$ software.

REML/BLUP model. This model was used for stability and adaptability analysis. The harmonic mean of genotypic values was obtained by the equation $\mathrm{HMGV}=e / \sum_{j=1}^{e}\left(1 / G V_{i j}\right)$, where $(e)$ is the number of environment in which genotype $(i)$ was evalued, $\left(G V_{i j}\right)$ is the genotypic value of genotype $(i)$ in environment $(j)$. For adaptability analysis, the relative performance of genotypic values (RPGV) across environments was obtained by the equation $\mathrm{RPGV}=(1 / e) \sum_{j=1}^{e}\left(G V_{i j} / \mu_{j}\right)$, where $\mu_{j}$ is the mean of environment $(j)$. The RPVG values are expressed as a proportion of the general mean (GM) for each location, subsequently obtaining the average value of these ratios from all locations. Finally, a simultaneous genotypic analysis of yield, stability and 
adaptability was performed using the harmonic mean of relative performance of genotypic values (HMRPVG), according to the equation HMRPVG $=e / \sum_{j=1}^{e}\left(1 / R P G V_{j}\right)$. The mixed model analysis, adaptability and stability analyses were performed using the Selegen REML/BLUP software (M. Vilela de Resende. Univ. Fed. Vicosa 2007. Unpublished data).

\section{RESULTS AND DISCUSSION}

The analysis of variance for rice yield at six environments indicated that the effects of genotype, environment and the GEI on yield were significant $(P \leq 0.05)$, with a percentage of the total treatment variation of $19.3 \%$ for genotype, $64.7 \%$ for the environment and $16.4 \%$ for interaction. Similar results were achieved by Acevedo et al. (2019) in rice varieties. In general, environmental effects are the main determinants of phenotypic expression and adaptation of genotypes. For upland rice crop, on average, it was observed that the contribution ratio of the $\mathrm{G}$ : E: GE effects is close to 1:4:2 (Costa et al., 2020). The evaluation of genotypes in multiple locations and years in rice for yield has shown that the greatest variation is concentrated in the locations effect (Regitano et al., 2013; Colombari et al., 2013).

The decomposition of the degrees of freedom of genotypes, through orthogonal contrasts, detected differences $(P \leq 0.05)$ for the interaction of hybrids by localities. This shows that the performance of the hybrids was differential between the test locations. The average grain yield for varieties, hybrids and general average was 7.7; 7.3 and $7.4 \mathrm{Mg} \cdot \mathrm{ha}^{-1}$, respectively.

The presence of significant GEI for grain yield in rice hybrids was detected in others works (Ponnuswamy et al., 2018; Huang et al., 2017 and Yuan, 2017), a challenge that the rice breeders must face, because it affects the recommendation of new cultivars, as well as estimates of genetic parameters.

The mean yield of the hybrids varied from 3.7 to $10.8 \mathrm{Mg} \cdot \mathrm{ha}^{-1}$ (G5 and G6), and from 4.6 to 9.7 $\mathrm{Mg} \cdot \mathrm{ha}^{-1}$ (V3 and V4) for the varieties, while the mean yield for locations varied from 5.0 to 8.9 $\mathrm{Mg} \cdot \mathrm{ha}^{-1}$ (L5 and L6) (Table 2). The genotypes with maximum yield by locations were the hybrid H6 in L2, L5 and L6, followed by the varieties V4 and V1 in L1 and L3, respectively, and the hybrid $\mathrm{H} 3$ in L4. The H5 and H1 hybrids had the worst performance in all environments. Locations with the best mean yields were L6, L2, and L3 in decreasing order and the worst was L5.

Table 2. Grain yield average $\left(\mathrm{Mg} \cdot \mathrm{ha}^{-1}\right)$ of ten rice genotypes in six localities, season 2015-2016

\begin{tabular}{clccccccc}
\hline \multirow{2}{*}{$\begin{array}{c}\text { Biplot } \\
\text { label }\end{array}$} & Genotype & L1 & L2 & L3 & L4 & L5 & L6 & $\begin{array}{c}\text { Mean } \\
\text { Tukey } \\
(P \leq 0.05)\end{array}$ \\
\cline { 3 - 7 } H1 & HL23057H(A) & 4.17 & 9.74 & 7.83 & 6.70 & 4.55 & 8.53 & $6.92 \mathrm{bdc}$ \\
H2 & HL23057H (B) & 7.52 & 8.81 & 6.96 & 8.30 & 4.85 & 8.68 & $7.52 \mathrm{abc}$ \\
H3 & HL23035H & 7.59 & 9.28 & 8.11 & 7.95 & 4.82 & 9.51 & $7.88 \mathrm{ab}$ \\
H4 & HL23021H & 4.84 & 7.79 & 6.71 & 6.97 & 4.33 & 7.98 & $6.44 \mathrm{~cd}$ \\
H5 & RHA-147 & 6.84 & 7.69 & 6.58 & 5.60 & 3.71 & 7.46 & $6.31 \mathrm{~d}$ \\
H6 & RHA-180 & 8.58 & 10.77 & 7.77 & 7.31 & 6.09 & 10.55 & $8.51 \mathrm{a}$ \\
V1 & SD20A & 8.64 & 9.01 & 8.97 & 7.37 & 5.44 & 8.88 & $8.05 \mathrm{ab}$ \\
V2 & Payara FL & 5.06 & 7.92 & 7.12 & 7.08 & 5.73 & 8.96 & $6.98 \mathrm{bcd}$ \\
V3 & Pionero FL & 6.64 & 8.78 & 7.66 & 7.94 & 4.61 & 9.25 & $7.48 \mathrm{abc}$ \\
V4 & Soberana FL & 8.91 & 8.89 & 8.66 & 8.12 & 5.87 & 9.37 & $8.30 \mathrm{a}$ \\
\hline Mean Tukey $(P \leq 0.05)$ & $6.88 \mathrm{~b}$ & $8.87 \mathrm{a}$ & $7.64 \mathrm{~b}$ & $7.33 \mathrm{~b}$ & $5.00 \mathrm{c}$ & $8.92 \mathrm{a}$ & 7.44 \\
\hline
\end{tabular}

(L1) INIA Guárico, (L2) Plot 178 (Guárico), (L3) Plot 199 (Guárico), (L4) Plot Aproscello (Portuguesa), (L5) Plot Asoportuguesa (Portuguesa) and (L6) INIA Barinas. H1 - H6 corresponds to hybrids and V1-V4 check varieties. LSD Mean analysis by the method of the least significant difference. Means followed by the same letter are not different (Tukey, $P>0.05$ ) 
It is possible to explain that the high variation in the yield of hybrids and varieties in rice due to the environmental effect, which represented about $65 \%$ of the total variation, indicating the high diversity between the test locations and the effect of the interaction on genes that determine yield, justifying the analysis of adaptability and stability for genotypes and test locations.

AMMI analysis. The mean yield of hybrids and varieties by locations showed that the predominant interaction was complex, due to the different ways of classifying genotypes among locations. The AMMI analysis revealed that the first two PCs explained $77 \%$ (PC1 $58 \%$ and PC2 $19 \%$ ) of the GEI; in other works in hybrids and rice varieties, the first two PCs have explained $72.77 \%$ (Acevedo et al., 2019), $46.62 \%$ (Ponnuswamy et al., 2018), $65.64 \%$ (Haider et al., 2017) and $67.90 \%$ (Samonte et al., 2005).

The biplots were used to visualize the performance of different genotypes in a given environment (Figure 1). The best genotypes are considered to have high yield and stability in most locations; in this case, five materials, H6, V4, V1, $\mathrm{H} 3$ and $\mathrm{H} 2$, presented a yield above the general mean, of which three corresponds to hybrids and two are local varieties. However, genotypes with low PC1, close to zero, hardly contribute to the interaction and are considered stable; these were the hybrids $\mathrm{H} 3, \mathrm{H} 6$, and $\mathrm{H} 2$, followed of the variety V3, while the hybrid H6 was considered the most desirable genotype because it had high yield and stable, followed by the HIAAL H3 hybrid.

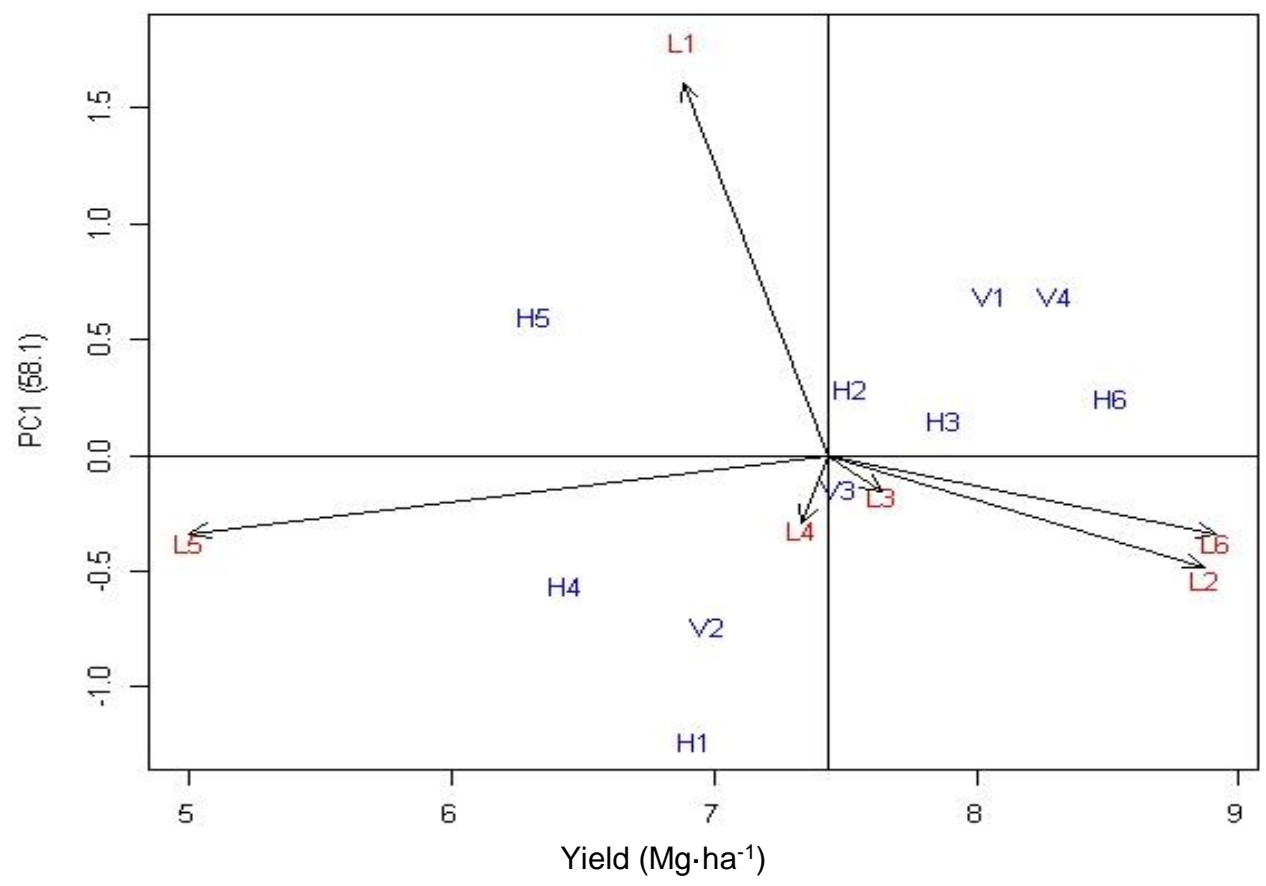

Figure 1. Biplot AMMI 1 of grain yield of hybrids $(\mathrm{H})$ and rice varieties (V) in six localities (L) of Venezuela

The varieties V1 and V4 were unstable, presented interaction positive type in $\mathrm{L} 1$ and negative with the rest of the localities, adaptive capacity that allows to take advantage of the GEI for the selection based on its specific adaptability. These results coincided with those presented by Acevedo et al. (2019) for the variety V1, and contradicts the high stability previously shown by V4 in trials among Venezuelan rice varieties.
The hybrids $\mathrm{H} 1$ and $\mathrm{H} 4$ showed instability and lower than average grain yield, with negative interaction in L1 and positive in the L4, as well as the variety V2. The hybrid H5 showed the lowest yield and positive interaction in L1 and negative with the rest of the locations. In general, according to the AMMI model, $\mathrm{H} 1, \mathrm{H} 4, \mathrm{H} 5$ and $\mathrm{V} 2$ contributed more to the interaction and had low adaptation in all locations. These results 
demonstrated the high complexity of the genotype by environment interaction phenomenon and the need to perform genotype evaluations in time and space.

In the AMMI 1 model, the localities L3 and L4 have low magnitude vectors, but stable, with low GEI contribution. This environment type is considered useful, since the classification of the materials is determined mainly due to the genotype effect, because the interaction is practically null, and depending on the objective, these locations are not recommended for selection of adapted genotypes. The opposite occurred with the remaining locations L1, L2, L5 and L6, which showed large-scale vectors with high contribution to the interaction that lead to classify different genotypes.

These results coincided with those presented by Acevedo et al. (2020) for localities L1 and L5 but not for L6 for irrigated rice varieties. Nevertheless, the four localities allowed better expression of genetic potential and better differentiation through them, although the phenotype is influenced by an important GEI contribution.

Locations L2 and L6 have an angle less than $90^{\circ}$ and classify the genotypes similarly, which would allow the substitution of one by another; however, these locations belong to different producing regions, with well differentiated management, and for which, an evaluation for several years is recommended. On the contrary, vectors between locations with an angle close to $180^{\circ}$ as L5 with L3 and L6 ordered genotypes in reverse, affecting the recommendation and breeder selection (Crossa et al., 1990; Yan et al., 2000).

SREG model using GGE biplot. The PC1 and PC2 captured a high proportion of the genotype effects $(64.56 \%)$ and GEI (17.59\%), totaling $82.15 \%$ variability. These results were superior to those presented by Ponnuswamy et al. (2018) and Haider et al. (2017) in hybrids and varieties of rice studied by the same model.

The GGE biplot polygon is made up of the union of line segments between the farthest genotypes of the origin biplot, located at the vertices, representing the best or worst in yield in one or group of locations which facilitates the identification of mega-environments and GEI visualization (Sincik et al., 2021).

The "which won where" GGE biplot in Figure 2 showed that the V4 and V1 varieties, and the hybrid H6, were the best in the locality L1, while the hybrids $\mathrm{H} 6$ and $\mathrm{H} 3$ were superior in the L2, L6, L3, L4 and L5 localities. The variety V2 and hybrids $\mathrm{H} 1, \mathrm{H} 4$ and $\mathrm{H} 5$ had the worst performance in all test environments; similar result was observed in AMMI 1.

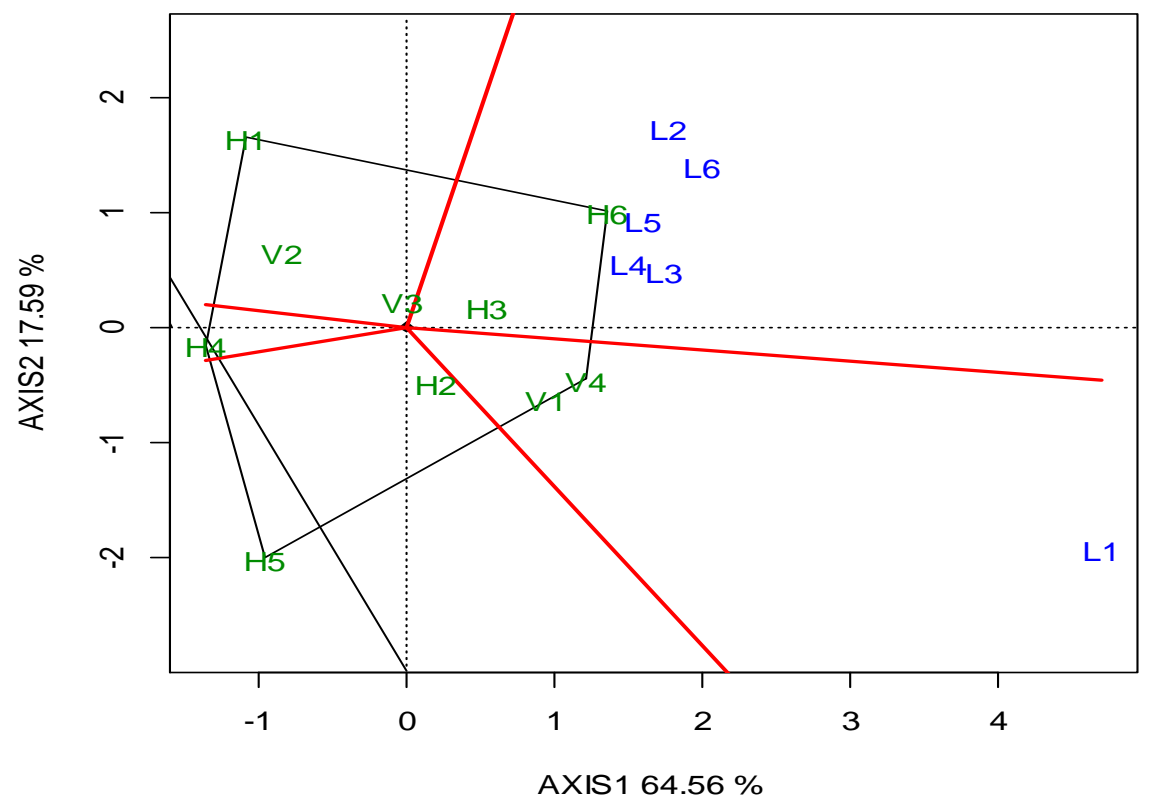

Figure 2. GGE Biplot "which won where" grain yield of hybrids $(\mathrm{H})$ and varieties $(\mathrm{V})$ of rice in different localities (L) 
The environments grouped in a sector having a winning genotype were considered as megaenvironments (Yan and Kang, 2003). The test locations could be divided into two mega environments; the mega-1 contains the hybrids H6 with the best grain yield followed by the HIAAL hybrid H3. The mega-2 is formed by varieties V4 and V1, with V4 being the top genotype. The variety $\mathrm{V} 3$, around the origin of the biplot suggests a moderate average performance in all test locations. The other sectors did not group locations and the rest of the genotypes were poor in all locations, coinciding with the AMMI analysis. However, it is important to point out what was reported by Yan et al. (2001), who highlight that in the studies for megaenvironments determination, various locations should be considered during several testing years, in order to define the groups of environments that consistently define the best cultivars or genotypes.
Mean vs. stability by the GGE biplot. The GGE "means - stability" biplot projects the distribution of hybrids and varieties, on the average environment coordinate (AEC), which is defined by the average of the scores of the PC1 and PC2 for all locations (Figure 3), the circle represented the mean of the AEC while the arrow meant the genotypes with superior performance, allowing to identify superior and stable genotypes, based on the average performance across all locations (Yan and Rajcan, 2002). The "ideal cultivar was the H6 hybrid which presented a high yield and stable, being located near the center of the concentric circles. However, genotypes located near the ideal genotype are considered "good genotypes," such as V4, V1 and H3. In Latin America, rice hybrids have gained strategic importance in research and development in recent years, mainly on adaptability studies; however, there are no detailed studies on adaptability and stability (Torres, 2014).

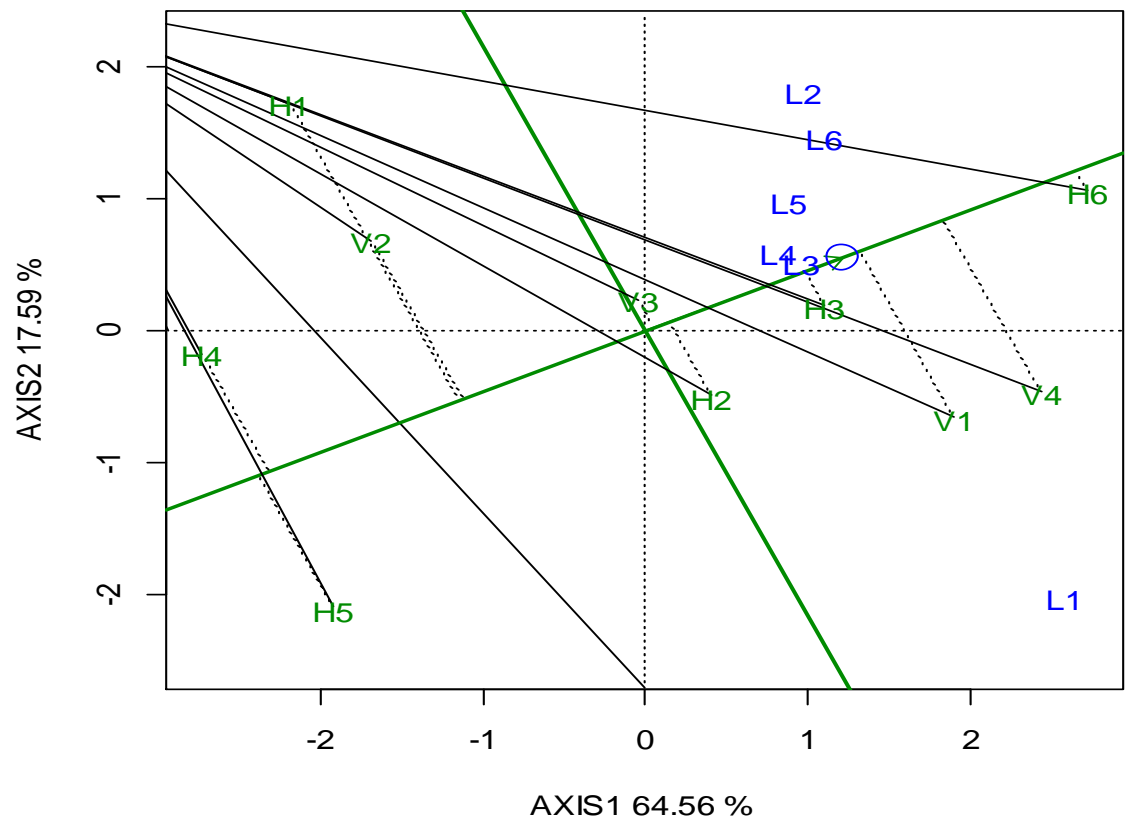

Figure 3. Biplot GGE "Mean - Stability" of hybrid (H) and varieties (V) genotypes of rice in six localities (L)

Distinguishing and representativeness of the test environments. The classification is based on identifying environments that help the breeder efficiently in the selection of superior genotypes for a mega-environment. The test locations with high capacity to discriminate or differentiate genotypes and representativeness for the purpose of study, to be considered an "ideal location"; this contributes to increasing the efficiency of selection and recommendation of new cultivars (Yan et al., 2000). The GGE biplot identified the L1 locality with a higher environmental vector, implying a better discrimination of hybrids and varieties (Figure 4). These results are in agreement with those obtained by Acevedo et al. (2020) which identified this location as appropriate for the 
selection of irrigated rice genotypes in both sowing seasons. However, the presence of GEI makes it difficult to identify ideal test locations (Yan et al.,
2000). The discriminating location helps identify genotypes with specific adaptation such as L1 for genotypes V1 and V4 for mega-environment 1.

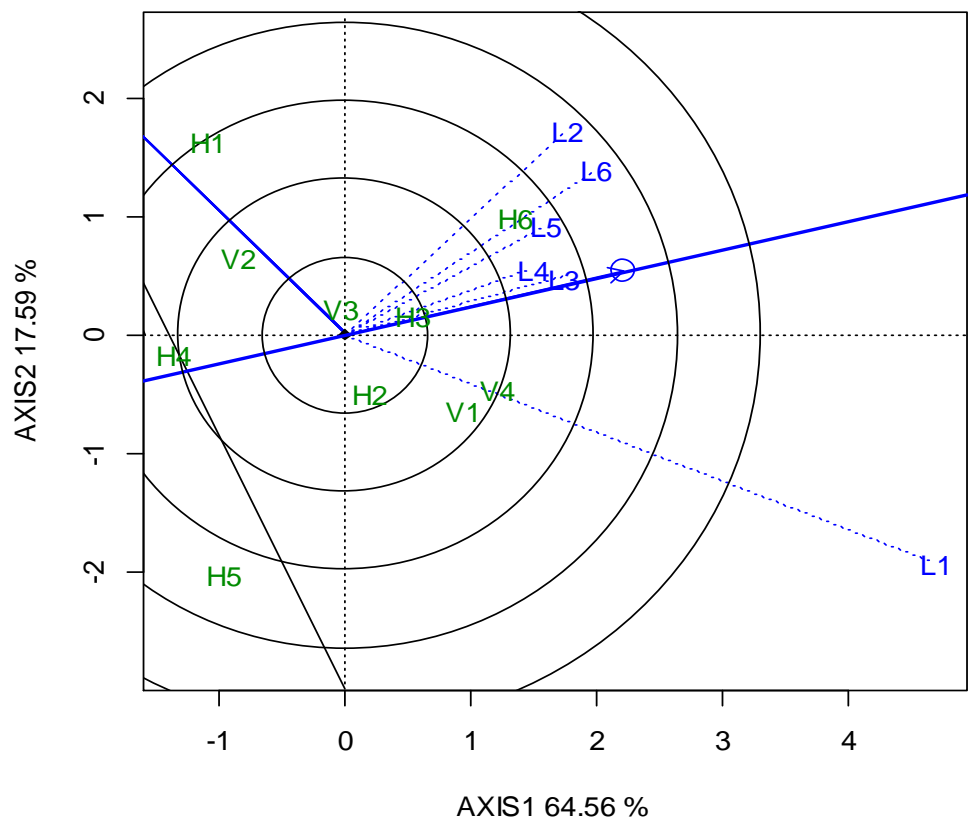

Figure 4. The discriminating vs representativeness view of theGGE biplot for rice genotypes in six localities

Agroclimatic factors, in general, become less important in the model proposed by Yan et al. (2000), since the main effect of genotype and GEI are considered together, being the most important adaptive capacity of genotypes at the time of cultivar selection and mega-environment formation than agro-climatic conditions (Camargo et al., 2011). The representativeness of the environment is given by the lower angle (acute angle) in relation to the AEC, so the most representative locality was L3 and L4, useful in identifying genotypes adapted for mega-environment 2 . These results are contrary to those found by the AMMI 1 analysis, where both localities were considered little discriminatory of rice genotypes.

REML/BLUP mixed model. The mixed REML / BLUP model showed a decreasing order of genotypes based on their genetic values, showing estimates of stability (HMGV), adaptability $\left(\mathrm{RPGV}^{*} \mathrm{GM}\right)$, as well as grain yield, adaptability and stability of genotypic values, simultaneously (HMRPGV*GM), (Table 3).

The $\mathrm{HMGV}, \mathrm{RPGV}^{*} \mathrm{GM}$ and criteria ranked similarly hybrids and rice varieties across environments with $100 \%$ coincidence, possibly attributed to the moderate magnitude of the genotypic correlation value across localities, indicating a high level of GEI, with a high proportion $(80 \%)$ of type simple interaction (non crossover), result differential change of mean, but not of ranking of different genotypes (Ramalho et al., 2012). The recommendation for hybrids and varieties should be made for each location or for one set of locations. Colombari et al. (2013) and Regitano et al. (2013) obtained results with 80 and $100 \%$ coincidence in upland rice, respectively, while Gonçalves et al. (2020) reported $87 \%$ coincidence in soybean.

The HMRPGV*GM method identified high productivity, adaptability and stability simultaneously of the H6, V4, V1 and H3 genotypes. The selection of the two experimental hybrids H6 and H3 (V4 and V1 are cultivars), would impact the general mean by $18 \%$, capitalizing on environmental improvement between localities and penalizing instability. Furthermore, this method estimates genotypic values on the same character measurement scale. 
Table 3. Estimates of $\mathrm{HMGV}, \mathrm{RPGV}^{*} \mathrm{GM}$ and $\mathrm{HMRPGV}{ }^{*} \mathrm{GM}$ to grain yield of rice genotypes

\begin{tabular}{clccc}
\hline Label & \multicolumn{1}{c}{ Genotype } & HMGV & PRVG*MG & MHPRVG*MG \\
\hline H6 & HL23057H(A) & 8.1 & 8.4 & 8.4 \\
V4 & HL23057H (B) & 8.0 & 8.3 & 8.2 \\
V1 & HL23035H & 7.7 & 8.0 & 8.0 \\
H3 & HL23021H & 7.5 & 7.8 & 7.8 \\
H2 & RHA-147 & 7.2 & 7.5 & 7.5 \\
V3 & RHA-180 & 7.2 & 7.5 & 7.0 \\
V2 & SD20A & 6.8 & 7.0 & 6.9 \\
H1 & Payara FL & 6.6 & 6.9 & 6.5 \\
H4 & Pionero FL & 6.2 & 6.5 & 6.4 \\
H5 & Soberana FL & 6.1 & 6.4 & \\
\hline
\end{tabular}

HMGV, RPGV, HMRPGV and MG, refers to the harmonic mean of genotypic values, the relative performance of genotypic values and the harmonic mean of relative performance of genotypic values and General Mean $\left(7.4 \mathrm{Mg} \cdot \mathrm{ha}^{-1}\right)$, respectively

\section{CONCLUSIONS}

The AMMI, GGE biplot, and REML/BLUP models coincided and identified the RHA-180 hybrid as the desirable genotype with greater productivity, adaptability and stability.

The first two models identified the variety 'Soberana Fl' as the best yield, with specific adaptation to the INIA Guárico location, not coinciding in this last aspect with the mixed model.

The GGE biplot analysis method was effective in grouping the six test environments into two mega-environments, having as superior genotypes 'RHA-180' and 'Soberana FL'. Thus, this model was considered the most effective, informative and complete for genotype by environment interaction analysis and evaluation in hybrids and rice varieties in Venezuela.

\section{ACKNOWLEDGEMENTS}

The authors would like to thank the institutions INIA Venezuela, Foundation DANAC, Aproscello, Asoportuguesa and FLAR-CIATColombia for supporting the research.

\section{LITERATURE CITED}

1. Acevedo-Barona, M., E. Reyes, W. Castrillo, O. Torres, C. Marín, R. Álvarez et al. 2010 Estabilidad fenotípica de arroz de riego en Venezuela utilizando los modelos Lin-Binns y AMMI. Agronomía Tropical 60: 131-138.

2. Acevedo-Barona, M., R. Álvarez, R. Silva, O. Torres and E. Reyes. 2019. Interacción genotipo ambiente en arroz para identificar mega-ambientes y ambientes ideales mediante el modelo de Regresión por sitios (SREG) and biplot GGE. Bioagro 31(1): 35-44.

3. Acevedo-Barona, M., R. Silva-Díaz, R. Álvarez-Parra, O. Torres-Angarita and E. Reyes-Ramone. 2020. Environmental stratification of rice by genotype $\mathrm{x}$ environment interaction analysis using five methods. Agronomía Mesoamericana 31(1): 43-57.

4. Camargo-Buitrago, I., E. Mc Intire and R. Gordón-Mendoza. 2011. Identificación de mega-ambientes para potenciar el uso de genotipos superiores de arroz en Panamá. Pesquisa Agropecuaria Brasileira 46(9): 16011069.

5. Colombari-Filho, J., M. de Resende, O. de Morais, A. de Castro, E. Guimarães, J. Pereira et al. 2013. Upland rice breeding in Brazil: a simultaneous genotypic evaluation of stability, adaptability and grain yield. Euphytica 192: 117-129.

6. Costa-Neto, G.M., J.B. Duarte, A.P. de Castro and A.B. Heinemann. 2020. Uso de infromação ambientais na modelagem e interpretação da interação genótipo x ambiente. Revisao bibliográfica. Boletim de pesquisa e desenvolvimento 56. Embrapa arroz e feijão. $46 \mathrm{p}$.

7. Crossa, J., H. Gauch Jr. and R. Zobel. 1990. Additive main effects and multiplicative interaction analysis of two international maize cultivar trials. Crop Science 30(3): 493- 500.

8. FAO. 2020. FAOSTAT. Roma. 
http://www.fao.org/faostat/es/\#compare

(retrieved May 15, 2020).

9. Fujimoto, R., K. Uezono, S. Ishikura, K. Osabe, W. Peacock and E. Dennis. 2018. Recent research on the mechanism of heterosis is important for crop and vegetable breeding systems. Breeding Science 68(2): 145-158.

10.García-Mendoza, P., I. Pérez-Almeida, G. Prieto-Rosales, D. Medina-Castro, D. Sánchez, C. Marín-Rodríguez et al. 2021. Interacción genotipo ambiente y potencial productivo de 25 variedades de maíz amiláceo en la provincia de Tayacaja, Perú. Bioagro 33(2): 67-78.

11.Gauch, H.G. 1992. Statistical Analysis of Regional Yield Trials. AMMI Analysis of Factorial Designs. Elsevier Science, Amsterdam.

12.Gonçalves, G.M.C., R.L.F. Gomes, A.C.A. Lopes and P.F.M. Vieira. 2020. Adaptability and yield stability of soybean genotypes by REML/BLUP and GGE Biplot. Crop Breeding and Applied Biotechnology 20(2): 1-9.

13.Haider, Z., M.A. Akhter, A. Mahmood and R. Khan. 2017. Comparison of GGE biplot and AMMI analysis of multi- environment trial (MET) data to assess adaptability and stability of rice genotypes. African journal of Agricultural Research 12(51): 3542-3548.

14.Huang, M., T. Qi-Yuan, A. He-Jum and Z. Ying-Bin. 2017. Yield potential and stability in super hybrid rice and its production strategies. Journal of Integrative Agriculture 16(2): 10091017.

15.INIA. 2020. Instituto Nacional de Investigaciones Agrícola. Red meteorológica de Venezuela. http://www.agrometeorologia. inia.gob.ve/index.php/la-red-rai (retrieved March 20, 2020).

16.Liu, J., M. Li, Q. Zhang., X. Wei and X. Huang. 2019. Exploring the molecular basis of heterosis for plant breeding. Journal of Integrative Plant Biology 62(3): 287-298.

17.Ponnuswamy, R., A. Rathore, A. Vemula and R. Das. 2018. Analysis of multi-location data of hybrids rice trials reveals complex genotype by environment interaction. Cereal Research Communications 46(1): 146-157.

18. Ramalho, M., J. Dos Santos, A. Abreu and J. Nunes. 2012. Aplicação da Genética Quantitativa no Melhoramento de Plantas Autógamas. Ed-Lavras. Universidade Federal de Lavras, UFLA.

19.Regitano-Neto, A., E. Ramos Júnior, P. Gallo, J. de Freitas and L. Azzini. 2013. Comportamento de genótipos de arroz de terras altas no estado de São Paulo. Revista Ciência Agronômica 44: 512-519.

20.Samonte, S., L. Wilson, A. McClung and J. Medley. 2005. Targeting cultivars onto rice growing environments using AMMI and SREG GGE biplot analysis. Crop Science 45: 24142424.

21.Sincik, M., A.T. Goksoy, E. Senyigit, Y. Ulusoy, M. Acar, S. Gizlenci et al. 2021. Response and yield stability of canola (Brassica napus L.) genotypes to multienvironments using GGE biplot analysis. Bioagro 33(2): 105-114.

22.Torres, E. 2014. Desarrollo de híbridos de arroz para América Latina "Un desafío para la investigación en mejoramiento de arroz". https://n9.cl/1fofe (retrieved March 10, 2020).

23. Yan, W., L. Hunt, Q. Sheng and Z. Szlanvnics. 2000. Cultivar evaluation and megaenvironment investigation based on GGE biplot. Crop Science 40(3): 597-605.

24. Yan, W. and I. Rajcan. 2002. Biplot analysis of test sites and trait relations of soybean in Ontario. Crop Science 42: 11-20.

25.Yan, W. and M. Kang. 2003. GGE Biplot Analysis: A Graphical Tool for Breeders, Geneticists and Agronomists. CRC Press. Boca Raton, FL, USA.

26. Yuan, L.P. 2017. Progress in super-hybrid rice breeding. The Crop Journal 5: 100-102.

27.Zobel, R., M. Wright and G. Gauch. 1988. Statistical analysis of a yield trial. Agronomy Journal 80: 388-393. 